\title{
Influence of Social Media Usage on the Green Product Innovation of Manufacturing Firms through Environmental Collaboration
}

\author{
Norhuda Salim ${ }^{\circledR}$, Mohd Nizam Ab Rahman*, Dzuraidah Abd Wahab® and \\ Ariff Azly Muhamed \\ Faculty of Engineering and Built Environment, Universiti Kebangsaan Malaysia, Bangi 43600, Malaysia; \\ norhuda.ukm@gmail.com (N.S.); dzuraidah@ukm.edu.my (D.A.W.); ariff.ukm@gmail.com (A.A.M.) \\ * Correspondence: mnizam@ukm.edu.my
}

Received: 3 August 2020; Accepted: 15 October 2020; Published: 20 October 2020

check for updates

\begin{abstract}
Firms are finding it increasingly important to leverage social media to facilitate knowledge access, get valuable feedback, and improve innovations to cater for emerging markets. However, using social media without integrating other key factors does not seem to add value to innovation efforts. Therefore, this study investigates the potential of social media usage (SMU) in enhancing green product innovation (GPI) and how two types of environmental collaboration may affect that relationship, which is a subject that has been under-explored. First, the literature on the expansion of the use of social media in enhancing GPI was reviewed to develop the theoretical framework and hypotheses. Then, data collected from 211 manufacturing firms were analysed using structural equation modelling to examine the proposed relationship. The results revealed that SMU does not directly influence GPI. Rather, internal environmental collaboration (IEC) and environmental collaboration with suppliers (ECS) fully mediate the relationship between SMU and GPI. The results further disclosed a positive relationship between IEC and ECS, where both types of environmental collaboration seem to be key factors in improving GPI. Hence, this study highlights the importance of knowledge sharing through environmental collaborations for the generation of ideas to improve products in order to remain competitive in the market.
\end{abstract}

Keywords: social media usage; green product innovation; environmental collaboration; environmental knowledge

\section{Introduction}

The need to support green growth and adhere to environmental regulations is increasingly compelling manufacturing firms to be more proactive in finding new information that can assist in improving their green practices and developing green products. As such, firms increasingly appreciate and seek to take effective advantage of the benefits of social media because it can be the best platform through which to disseminate information [1,2] and exchange information to gain new insights and additional knowledge [3]. Social media-which is defined here as encompassing social networking sites, microblogs, image and video-sharing applications, and collaborative websites-is increasingly attracting research interest globally because of its powerful and widespread impact on social interaction [4].

Previous studies on social media usage (SMU) and green product development have tended to focus more on the behaviour of consumers, rather than on the green performance of firms. For instance, several studies have found that SMU fosters pro-environmental action among consumers [5,6] and increases green consumerism or green purchases in various contexts [7]. However, at the firm level, 
the studies on the influence of SMU on the green performance of firms are very limited; thus far they have only considered green supply chain management $[8,9]$ and the sustainable performance of firms [10] in a very broad context. Moreover, it has been argued that the effects of social media on green practices are complex and, as yet, they are not well understood $[8,11]$. Therefore, given this current lack of understanding, it is not surprising that many firms, including green firms, are incapable of leveraging the benefits of social media and are unable to identify the significant factors associated with the effective use of this form of media [4,12]. Yet, clearly, green firms need to be more active in utilizing social media because they need to remain economically competitive while producing sustainable products and promoting a greener image to their customers and communities $[13,14]$. Therefore, there is a need to further investigate how social media can contribute to green business practices, especially in respect of the GPI of manufacturing firms because it seems that, thus far, this relationship has not been explored [15]. Such research is important because social media provides a wealth of up-to-date information on green issues that firms need to capture in order to innovate and compete effectively in a dynamic market. While an increasing number of recent studies have linked social media with the implementation of innovation [3,16-20], such investigations have not yet addressed the issue of green innovation. In this regard, in a review of existing studies, Bhimani et al. [21] concluded that the influence of SMU on innovation needs to be investigated through a more robust multidisciplinary lens, which would require further research to be undertaken on potential mediators or indirect effects, and furthermore, such research would also need to consider the various stages, organizational resources, and competences in the relationship.

According to the knowledge-based view, converting raw input from various sources into useful information to develop competitive strategies may bring real benefits to a business [22]. Therefore, it can be postulated that, through the use of social media, firms can gain value by cooperating with various parties that can contribute to the innovation effort $[16,23]$. In the context of green product development, the environmental collaborations practised by a firm have the potential to translate the benefits of social media into green practices more generally. In this regard, a recent study shows that environmental collaboration mediates the effect of social capital and capacity building on environmental performance [24]. In addition, it has been proven that internal environmental collaboration (IEC) mediates the relationship between advanced manufacturing technologies and green innovation [25], while environmental collaboration with suppliers (ECS) improves the financial performance of firms when practising green initiatives [26]. These findings underline the importance of environmental collaboration in improving green practices especially in the area of innovation, where these practices are concerned with reducing environmental impact and also making cost savings. On the other hand, studies have also shown that ECS does not help to improve the sustainability of the manufacturing process [27] and does not assist in eco-innovation [28]. However, those findings relate specifically to the food and beverage and the hospitality industries that may differ from the manufacturing industry in terms of operational processes and strategic focus because, according to Segarra-Oña et al. [29], manufacturing firms are more oriented towards the environment than service firms. Given the mixed findings across industries, further studies are needed in order to further enrich the literature in this area and to expand on previous research.

In light of the above, this study aims to address three key issues. Firstly, we attempt to clarify the relationship between the SMU and GPI of manufacturing firms. Secondly, we try to determine whether IEC and ECS mediate the relationship between SMU and GPI in manufacturing firms. Thirdly, we seek to ascertain whether IEC helps to improve ECS in manufacturing firms. Hence, this study contributes to the literature by expanding knowledge on the potential of SMU in improving green product development.

Previous studies have shown that SMU has an influence on green performance even in limited contexts, but its effects on GPI have not been explored in depth. Moreover, the SMU indicators used in this study are tailored to suit the context of environmental activities and green products. This approach is in line with previous studies that have adapted SMU indicators to focus on other 
research areas, such as marketing, customer relations [12], general use [30], recycling activities [15], and innovation [31]. Finally, by adopting the resource-based view (RBV) and relational view and by using structural equation modelling (SEM) analysis, this study proposes a more comprehensive model in which IEC (internally driven) and ECS (external source) are linked together with SMU in order to examine the relationship between SMU and GPI. Thus, the results of the SEM analysis provide strategic managers with a better understanding of the direct and indirect relationships between SMU and GPI to enable them to prioritize more effectively the application of the key factors that govern these relationships.

The remainder of this paper is organized as follows: Section 2 presents the literature review and the hypotheses development; Section 3 explains the methodology used; Section 4 presents the results; Section 5 discusses the results; and lastly, Section 6 outlines the conclusion and implications of the study.

\section{Literature Review}

\subsection{Social Media and Knowledge}

Social media connects organizations, customers, stakeholders, and communities and empowers its users to communicate and collaborate using internal and external knowledge sources [19]. Social media platforms enable users to exchange and share information to gain new insights and additional knowledge [3]. According to the RBV perspective, manufacturing firms need to develop their capabilities in searching for current and valuable knowledge to achieve good performance in GPI in order to remain competitive in the market. In this regard, past studies have shown that having the capability to utilize the knowledge obtained from SMU may accelerate the innovation and the competitiveness of firms $[3,18]$. Various forms of knowledge can be obtained through feedback and two-way interactions with customers, users, and stakeholders, and such knowledge allows firms to identify preferences and expectations about upcoming new products [19]. Furthermore, SMU offers better methods of business collaboration because it enables the creation of collaborative knowledge and inspires effective knowledge sharing between firms that can lead to the generation of more competitive ideas [32], which, in line with relational theory, helps to improve firm performance. In the green context, environmental collaboration, which is specifically intended to exploit environmental knowledge to develop new ideas, is believed to foster GPI activities. Thus, this study draws on both the RBV and the relational theory perspective to develop a hypothesis model that explains the relation between SMU and GPI as well as the influence of IEC and ECS.

\subsection{SMU and GPI}

Green product innovation involves improving products by using eco-friendly designs that are aimed at reducing pollution, conserving resources, and minimizing environmental impacts [33]. Well-planned GPI can improve the environmental management performance of firms, help to reduce their environmental costs, and open up new market opportunities to increase competitive advantage [34]. Recent studies have shown that innovation capabilities can be enhanced through SMU because it can basically change the way firms communicate [19]. Social media is a powerful platform that allows users to tap into rich information, which in turn impacts their knowledge development, decision making, and organizational performance [35]. In this regard, Corral et al. [17] found that, in firms that practice modern human resource management, SMU has a direct effect on firm innovativeness. While this finding is not related to the green context, it is nevertheless plausible that SMU can also increase the GPI performance of firms.

The relationship between SMU and GPI can be expressed through the adoption of the RBV, which states that firms that have the ability to efficiently exploit and utilize resources in ways that are valuable, rare, inimitable, and non-substitutable can achieve sustainable competitive advantage [36]. In this respect, Mothe and Nguyen-Thi [37] argued that firms that actively engage in the pursuit of new 
knowledge and ideas from various sources will increase their chances of success. In terms of knowledge sources, social media is a valuable resource that continues to expand and a growing number of green firms are actively sharing information about the environment online because more firms are looking for information on green products and environmental practices [7]. Furthermore, Carlson et al. [23] claimed that consumers are increasingly open to participating voluntarily in providing feedback or ideas for product improvement through social media. They are also willing to share green information through social media sites such as Facebook, Twitter, etc., and to disseminate positive feedback on the health and environmental benefits of green products [38]. Therefore, in light of the above, it seems that SMU has the potential to be an important agent for the broader sharing of environmental or green information and could therefore greatly influence GPI. Based on this argument, the following hypothesis is proposed:

\section{Hypothesis (H1). There is a positive and significant relationship between SMU and GPI.}

\subsection{The Mediating Roles of IEC}

Although SMU is believed to spur GPI, the underlying mechanisms that drive the implementation of GPI itself have not been examined in detail. To fill this gap, this study intends to determine whether IEC acts as one of the mediators in the relationship between SMU and GPI. Internal environmental collaboration can be defined as the direct involvement of different divisions within an organization in jointly planning and developing environmental management strategies to enhance the organization's core competencies in utilizing knowledge for environmental innovation [25]. In this regard, the integration of other functions such as marketing, research and development, and production could lead to successful inter-functional collaboration [14]. The extensive environmental collaboration among employees including experts, analysts, and decision makers can be considered as a unique organizational capability from the perspective of RBV [39], and can be expected to translate SMU into better GPI performance. Currently, there are many social sites that promote high-quality green news and information by top green bloggers and social media contributors. However, employees need to be more proficient in sharing, screening, and extracting information because the poor handling of such information could create conflicts within the organization [40]. Thus, a presence of a high level of IEC would allow employees to find new ideas related to the environment from social media and further assimilate this new knowledge by structuring and integrating it into the existing knowledge base to enhance innovation [41]. In this regard, Rózewski et al. [42] pointed out that an efficient knowledge flow within the community of practice is vital because it can encourage the community members to be more proactive. Moreover, Fernando and Wah [43] argued that green innovation requires good communication and collaboration among cross-functional team members who are skilled in green practices such as reducing waste, conducting product life-cycle analyses, and gauging the compliance status of operations to improve manufacturing processes and product specifications. In addition, social media is accessible to many individuals in an organization and therefore connecting them to information derived from social media by giving them access to a common database that links various functional departments would be very helpful for sharing technical information, policies, and establishing common environmental goals [25].

In addition, GPI requires new knowledge and up-to-date information on how to improve product features that meet market needs and, at the same time, comply with various relevant policies [44]. Furthermore, GPI also requires the implementation of effective cost control measures [45]. Hence, knowledge needs to be integrated quickly and supported by efficient decision making [46]. Yet, making the right decisions that meet the triple bottom line of sustainability (i.e., its environmental, economic, and social aspects) is challenging because the trade-off between environmental and economic objectives requires deep knowledge [47]. Thus, IEC needs to be present in a firm because it supports the digestion of knowledge, which enables the exposure of the knowledge garnered from various sources and the reaching of more comprehensive and appropriate decisions. Moreover, IEC, as manifested in a green 
team, is mainly responsible for synergizing environmental communications to make knowledge flow more focused, dynamic and fast, and it also allows the better transfer of critical technical knowledge across multiple functions to ensure that a firm continues to be environmentally innovative [48]. Therefore, IEC is expected to promote the benefits of SMU in expediting GPI, as postulated in the following hypotheses:

Hypothesis (H2). IEC mediates the relationship between SMU and GPI.

Hypothesis (H2a). There is a positive and significant relationship between SMU and IEC.

Hypothesis (H2b). There is a positive and significant relationship between IEC and GPI.

\subsection{The Mediating Roles of ECS}

Environmental collaboration with suppliers is also considered to be an underlying factor that supports SMU in improving GPI. In this study, ECS encompasses sustainability accountability in supply chain relationships, including the leveraging of resources and the exploitation of knowledge opportunities with partners to induce environmental sustainability [27]. The appositeness of ECS in the context of this study is derived from relational theory [49], which views organizational relationships between firms as a key source of competitive advantage. A number of previous studies have integrated relational theory into models for supply chain collaboration in the green context and have addressed the relational value that is formed through the joint contributions of allied partners. For example, it has been found that such collaboration can result in reducing the consumption of raw materials, volume of disposed waste, use of toxic materials, and toxic emissions in product development and production [50]; in minimizing unnecessary packaging and increasing the use of recycled materials in operational processes [51]; in offering fresh ideas, methods, or technologies to manufacturers for developing products, and in building overall compliance with environmental regulations [52,53].

Moreover, ECS is believed to maximize the influence of SMU on GPI because ECS generates initiatives that drive firms to seek environmental knowledge through social media with a greater focus on the environmental goals they want to achieve. In this regard, Cao and Yu [40] pointed out that SMU needs to be strategically managed and well-directed because its improper or ineffective usage can negatively affect firm performance. Furthermore, ECS inspires firms to expand their business network and to adopt new technology to attract more opportunities to increase revenue while reducing supply risks [54]. Meanwhile, ECS can also enhance a firm's GPI because it provides access to new knowledge, enables learning, and facilitates the sharing of information on future market trends and new technologies to generate cutting-edge ideas that lead to innovation [55]. Moreover, Ardito et al. [56] argued that suppliers represent the most beneficial source of knowledge for enhancing innovation activities as compared to customers and competitors. This view is supported by a study that showed that collaboration with green suppliers enables the efficient use of their resources and the exploitation of knowledge opportunities to enhance environmental activities and drive cost savings [57], which are important for successful implementation of GPI. However, as mentioned earlier, some studies related to the food and beverage and the hospitality industries have found that ECS is not likely to assist firms to implement sustainable process and eco-innovation [27,28], which can affect the implementation of GPI. Therefore, it is important to further examine the role of ECS in fostering SMU to enhance the implementation of GPI in manufacturing firms by testing the following hypotheses: 
Hypothesis (H3). ECS mediates the relationship between SMU and GPI.

Hypothesis (H3a). There is a positive and significant relationship between SMU and ECS.

Hypothesis (H3b). There is a positive and significant relationship between ECS and GPI.

\subsection{The Relation between IEC and ECS}

Internal and external knowledge sharing must be prioritized because both have a great influence on a firm's success [58]. Demeter et al. [59] asserted that knowledge generated in an internal network should be combined with the expertise of external supply chain partners. By adopting this two-pronged knowledge-gathering and sharing strategy, more superior environmental knowledge would be generated, and would in turn motivate firms to adopt more proactive environmental strategies [60]. Furthermore, the integration of the tacit knowledge possessed by green suppliers has been shown to lead to the promotion of continuous innovation in the design of eco-friendly products [61,62]. This viewpoint is in agreement with Melander [45], who pointed out that firms that already have good internal knowledge management tend to share environmental knowledge outside the firm, particularly with competent suppliers that have environmental expertise, in order to reap the benefits of new environmental knowledge. It seems that firms with higher levels of knowledge sharing can connect internal and external collaboration in an effective way [59]. However, studies on the relationship between these two forms of collaboration in the green context remain scarce. Therefore, this study measures the influence of IEC on ECS by proposing a fourth and final hypothesis:

Hypothesis (H4). There is a positive and significant relationship between IEC and ECS.

Figure 1 depicts the hypothesis model developed for this study.

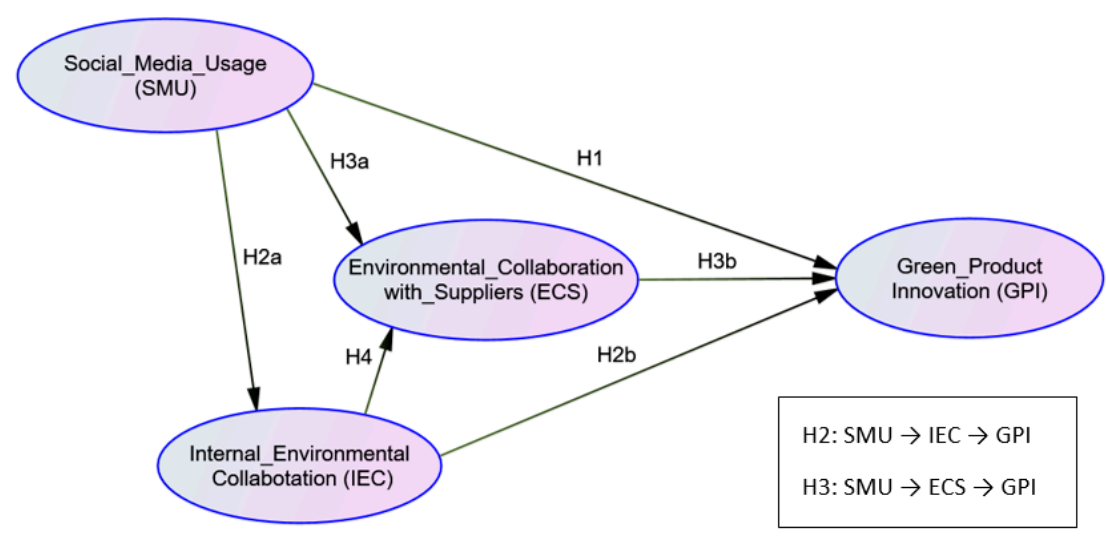

Figure 1. Hypothesis model. 


\section{Methodology}

\subsection{Data Collection and Sampling}

This study involved manufacturing firms registered with the Malaysia External Trade Development Corporation (MATRADE 2018). The firms represent all subsectors in the manufacturing industry and many of them export their products to countries around the world. The firms listed in the Malaysia Exporters Directory, which is a database compiled by MATRADE (http://www.matrade.gov.my), are committed to continuously improving their products and processes to comply with international standards including sustainability requirements. Hence this target group is believed to meet the needs of the survey conducted for this study. Seven hundred of the firms listed on the database were randomly sampled for this study. The middle- or upper-level managers of the selected firms were contacted via an email that directed them to the online questionnaire survey developed for this study. The email included a cover letter explaining the purpose of the survey and the assurance that the utmost level of confidentiality would be maintained. Data collection took place between December 2019 and June 2020. To increase the response rate, follow-up telephone calls were made two weeks after sending the email. At the end of the data collection process, 226 surveys were returned, representing a response rate of $32.3 \%$. After removing the invalid questionnaires, 211 useable questionnaires remained in the sample. This number was deemed sufficient for executing the analysis of the four constructs employed in the model [63]. To ensure the quality of the research findings, the possibility of the existence of common method bias was investigated using Harman's single-factor test. The results indicated that the first factor captured only $36.194 \%$ of the variance, which implied that common method bias was not a significant problem in this study.

\subsection{Measure}

Initially, the constructs used in this study were represented by 26 items that were adopted and adapted from previous research. The survey items were designed so that they could be answered by the respondents using a seven-point Likert scale [64] ranging from $1=$ "strongly disagree" to $7=$ "strongly agree". To ensure that the validity of the instrument for the field study, exploratory factor analysis (EFA) was conducted on each construct [65]. The Bartlett's test result showed a significance level of 0.000, which denoted that the constructs were well-correlated [66]. The Kaiser-Meyer-Olkin scores were above 0.8 (ranging between 0.833 and 0.871 ), which indicated that the data set was appropriate for the analysis [67]. Meanwhile, the total amount of the variance described by the items was found to be sufficient because it exceeded the minimum requirement of 60\% [65-67] (ranging between $60.26 \%$ and $66.07 \%$ ). The construct reliability was tested by using the Cronbach's alpha coefficient. The four constructs all exceeded the 0.7 threshold (ranging between 0.857 and 0.894 ) and therefore possessed acceptable reliability [66]. In addition, EFA was performed to identify whether any items had a weak factor loading of below 0.6. As a result, two items were removed from the model. Hence, 24 out of the 26 items were used in the confirmatory factor analysis (CFA) analysis (refer to Table 1 in Section 4).

\subsection{Model}

This study employed SEM for the data analysis, which was done using IBM-SPSS-AMOS software. This approach was adopted because SEM is the most efficient method for validating latent constructs and for analysing the causal paths among constructs simultaneously in a model [63]. Most importantly, it can be employed to test the hypotheses and mediators in a model [67]. 
Table 1. Factor Loadings of Measurement Items.

\begin{tabular}{|c|c|}
\hline Item & Factor Loading \\
\hline \multicolumn{2}{|l|}{ Social media usage $[68,69]$} \\
\hline $\begin{array}{c}\text { SMU1: Use social media to gather information about environmental issues/green } \\
\text { products from customers/suppliers/governments }\end{array}$ & 0.755 \\
\hline $\begin{array}{l}\text { SMU2: Use social media to collect information about competitor activities in } \\
\text { innovating green products }\end{array}$ & 0.742 \\
\hline $\begin{array}{l}\text { SMU3: Upload information about environmental issues/green products online to } \\
\text { discuss it with others }\end{array}$ & 0.711 \\
\hline $\begin{array}{c}\text { SMU4: Interact with more people when discussing a complicated theme regarding the } \\
\text { environment }\end{array}$ & 0.717 \\
\hline $\begin{array}{c}\text { SMU5: Frequently participate in online discussions to create new knowledge on } \\
\text { environmental activities/green products }\end{array}$ & 0.703 \\
\hline $\begin{array}{l}\text { SMU6: Voluntarily participate in professional online discussions related to } \\
\text { environmental activities/green products }\end{array}$ & 0.581 (deleted) \\
\hline \multicolumn{2}{|l|}{ Internal environmental collaboration $[25,70]$} \\
\hline IEC1: Achieve environmental goals together & 0.792 \\
\hline $\begin{array}{l}\text { IEC2: Mutual understanding of responsibility in overseeing environmental } \\
\text { performance }\end{array}$ & 0.772 \\
\hline IEC3: Collaborate to reduce environmental impact & 0.811 \\
\hline IEC4: Plan together to anticipate and solve problems related to the environment & 0.788 \\
\hline $\begin{array}{l}\text { IEC5: Make a joint decision on how to minimize the environmental impact of the } \\
\text { product }\end{array}$ & 0.775 \\
\hline \multicolumn{2}{|l|}{ Environmental collaboration with suppliers [71] } \\
\hline ECS1: Work with suppliers to attain environmental objectives & 0.801 \\
\hline ECS2: Provide suppliers with green design specifications for purchased items & 0.778 \\
\hline ECS3: Cooperate with suppliers to develop new resource reduction strategies & 0.784 \\
\hline ECS4: Collaborate with suppliers to improve waste reduction initiatives & 0.764 \\
\hline ECS5: Cooperate with suppliers to achieve a cleaner production process & 0.734 \\
\hline $\begin{array}{c}\text { ECS6: Collaborate with suppliers to acquire materials/parts that support } \\
\text { environmental goals }\end{array}$ & 0.760 \\
\hline \multicolumn{2}{|l|}{ Green product innovation $[33,72]$} \\
\hline GPI1: Choose materials that produce the least amount of pollution & 0.803 \\
\hline GPI2: Choose materials that consume the least amount of energy/resources & 0.763 \\
\hline GPI3: Modify product designs to substitute traditional materials with recycled ones & 0.750 \\
\hline GPI4: Consider whether products are easy to recycle, reuse, and decompose & 0.731 \\
\hline GPI5: Improve environmentally friendly packaging for products & 0.630 \\
\hline GPI6: New product sales revenue & 0.681 \\
\hline GPI7: Customer satisfaction & 0.689 \\
\hline
\end{tabular}




\section{Result}

\subsection{Demogaphic Profile}

Figure 2 provides the demographic profile of the respondents who provided valid responses. From the figure, it can be seen that $70 \%$ of the respondents were assistant managers, assistant directors or above. Furthermore, $77 \%$ of the respondents had worked for their company for more than 10 years. Employees in senior roles are more knowledgeable about their organization's strategic orientation [73] and are thus more likely to have a clear understanding of the organizational utilization of social media in retrieving environmental knowledge. Moreover, when respondents have extensive working experience, it enables them to provide quality feedback. Furthermore, the majority of the respondents $(68 \%)$ represented the electrical and electronics industry, the chemical industry, and the mechanical and equipment industry, all of which are key subsectors that drive the growth of the manufacturing sector in Malaysia. Hence it can be inferred that good-quality, pertinent data were obtained for the analysis.

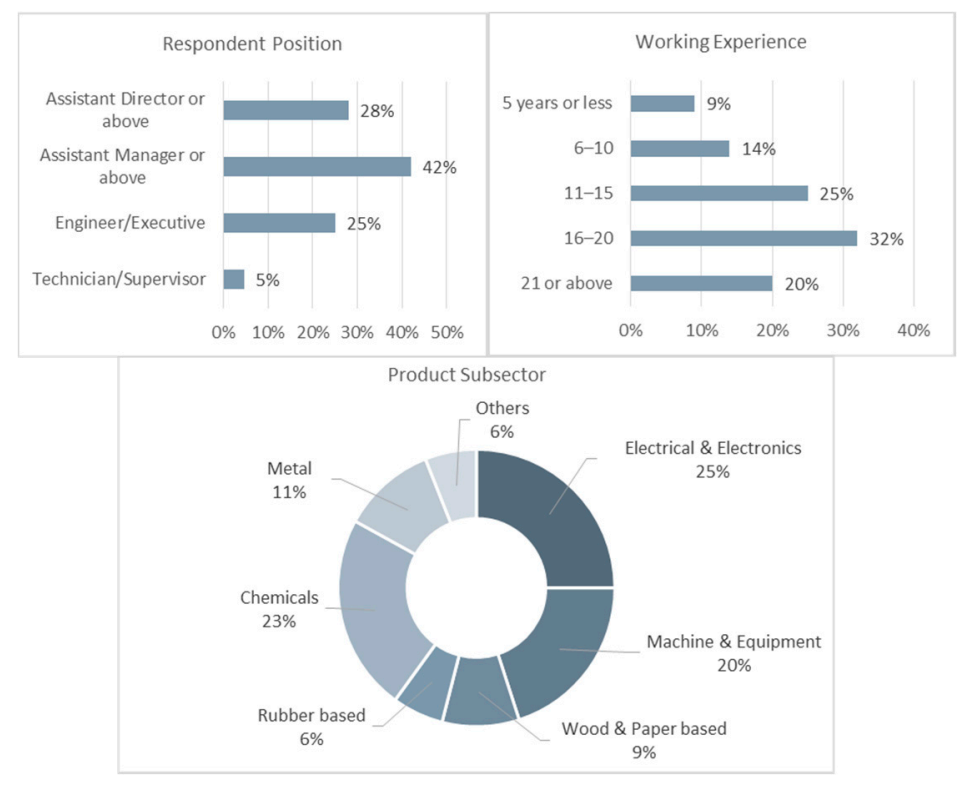

Figure 2. Demographic profile.

\subsection{Measurement Model}

The relationships between the four constructs and the 24 measurement items formed the measurement model for this study. Confirmatory factor analysis was carried out to assess the measurement model for unidimensionality and to examine the validity and reliability of the latent constructs. As shown in Table 1, all the factor loadings were greater than the minimum threshold of 0.6 [74,75], except for SMU6, which had a value of 0.581. Therefore, this item was deleted, thus allowing unidimensionality to be achieved. Accordingly, construct validity, convergent validity, and discriminant validity were then tested to examine the significance of the measurements items. The initial results for construct validity showed unacceptable values for the goodness-of-fit index (GFI), comparative fit index (CFI) and Tucker-Lewis index (TLI). As regards the modification indices (MI) measurement, a high MI value (>15.0) indicates that the respective items are redundant, which thus affects the discriminant validity of the model [75-77]. Upon examination, two covariance values, i.e., those between ECS4 and ECS5 and between GPI4 and GPI5, which were 21.23 and 19.78, respectively, had caused the poor fit of the model. Consequently, for this particular case, both pairs were set as 'free parameter estimates', which eventually resulted in improving the fitness indices and achieving acceptable values. The fitness indices for the final measurement model are presented in Table 2. 
Table 2. Fitness Indices of the Measurement Model.

\begin{tabular}{ccccc}
\hline Category & Index & Initial Index Value & Final Index Value & Level of Acceptance \\
\hline Absolute fit & RMSEA & 0.075 & 0.067 & $<0.08$ \\
& GFI & 0.853 & 0.907 & $>0.9$ \\
Incremental fit & CFI & 0.894 & 0.920 & $>0.9$ \\
& TLI & 0.882 & 0.921 & $>0.9$ \\
Parsimonious fit & Chisq/df & 1.670 & 1.688 & $<3$ \\
\hline
\end{tabular}

Note: RMSEA = Root Mean Square Error of Approximation; GFI = goodness of fit index; CFI = comparative fit index; $\mathrm{TLI}=$ Tucker-Lewis index; Chisq/df $=$ parsimony index.

In this study, as shown in Table 3, all the average variance extracted (AVE) values surpassed the threshold of $0.5[78,79]$, which indicated that all the items were significantly loaded onto their construct. In addition, the composite reliability (CR) values exceeded the basic threshold level of 0.70 [78], which denoted that the constructs were reliable and had internal consistency. Furthermore, as also shown in Table 3, the diagonal value representing the square root of the AVE for each construct was higher than the inter-construct correlation values in the rows and columns. This proved that all four constructs possessed discriminant validity. Furthermore, all the construct correlations were below 0.85 [79], which indicated that there were no multicollinearity problems in the study model.

Table 3. Reliability and Validity of the Measurement Model.

\begin{tabular}{ccccccc}
\hline & CR & AVE & GPI & SMU & IEC & ECS \\
\hline GPI & 0.884 & 0.523 & $\mathbf{0 . 7 2 3}^{\mathrm{a}}$ & & & \\
SMU & 0.848 & 0.527 & $0.514^{\mathrm{b}}$ & $\mathbf{0 . 7 2 6}$ & & \\
IEC & 0.891 & 0.621 & 0.667 & 0.532 & $\mathbf{0 . 7 8 8}$ & \\
ECS & 0.888 & 0.569 & 0.550 & 0.475 & 0.512 & $\mathbf{0 . 7 5 5}$ \\
\hline \multicolumn{7}{c}{ Note: $^{\mathrm{a}}$ square root of AVE; } \\
\end{tabular}

\subsection{Structural Equation Modelling and Hypothesis Testing}

\subsubsection{Standardized Path Coefficients}

Structural equation modelling was performed to test the proposed hypotheses. Figure 3 presents the standardized path coefficients of the generated model. In the model, the coefficient of determination $\left(\mathrm{R}^{2}\right)$ value for GPI was 0.52 , which indicated that the combined contribution of ECS, IEC, and SMU in estimating GPI was 52\%, a value that was deemed sufficient for this type of model [67].

\subsubsection{Hypothesis Testing}

The results of hypothesis testing are presented in Table 4, from which it can be seen that the statistical results support $\mathrm{H} 2 \mathrm{a}, \mathrm{H} 2 \mathrm{~b}, \mathrm{H} 3 \mathrm{a}, \mathrm{H} 3 \mathrm{~b}$, and $\mathrm{H} 4$, but surprisingly reject $\mathrm{H} 1$.

The supposition in hypothesis $\mathrm{H} 1$ that SMU would have a significant positive relationship with GPI is not supported. Although the direct link between SMU and GPI shows a positive result, it is insignificant $(\beta=0.198, p>0.1)$. As regards hypothesis $\mathrm{H} 2 \mathrm{a}$, the result indicates that SMU has a positive and significant relationship with IEC $(\beta=0.649, p<0.001)$, hence, hypothesis H2a is supported. Accordingly, the results also support hypothesis $\mathrm{H} 2 \mathrm{~b}$, where IEC exerts a significant positive relationship with GPI $(\beta=0.482, p<0.001)$.

The results also reveal that SMU has a positive and significant relationship with ECS ( $\beta=0.324$, $p<0.01$ ), thus hypothesis H3a is supported. Consequently, hypothesis H3b is also supported, where ECS has a significant positive relationship with GPI $(\beta=0.267, p<0.01)$. As regards the relation between internal and external collaborations, the result supports hypothesis $\mathrm{H} 4$, as it indicates that there is a significant positive relationship between IEC and ECS $(\beta=0.340, p<0.001)$. 


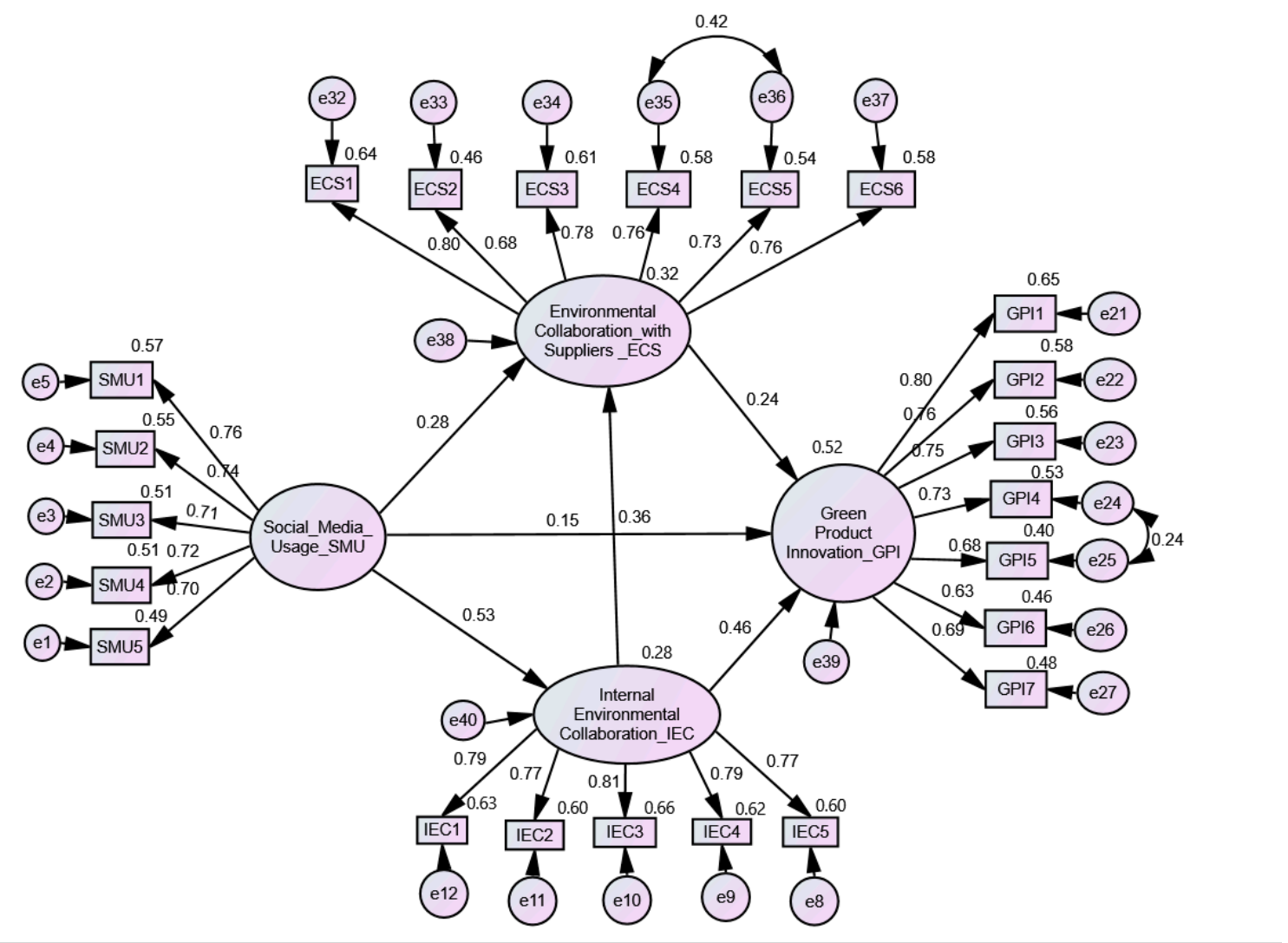

Figure 3. Standardized path coefficients.

Table 4. Results of Regression Path Analysis and Hypothesis Testing.

\begin{tabular}{ccccccc}
\hline \multicolumn{2}{c}{ Hypothesis } & $\boldsymbol{\beta}$ & SE & CR & $p$-Value & Result \\
\hline H1 & SMU $\rightarrow$ GPI & 0.198 & 0.118 & 1.671 & 0.105 & Not Significant \\
H2a & SMU $\rightarrow$ IEC & 0.649 & 0.122 & 5.312 & $* * *$ & Significant \\
H2b & IEC $\rightarrow$ GPI & 0.482 & 0.104 & 4.634 & $* * *$ & Significant \\
H3a & SMU $\rightarrow$ ECS & 0.324 & 0.120 & 2.699 & 0.007 & Significant \\
H3b & ECS $\rightarrow$ GPI & 0.267 & 0.100 & 2.667 & 0.008 & Significant \\
H4 & IEC $\rightarrow$ ECS & 0.340 & 0.097 & 3.511 & $* * *$ & Significant \\
\hline
\end{tabular}

Note: ${ }^{* * *}=p<0.001$.

\subsection{Mediation Analysis}

The analysis found that the direct relationship between SMU on GPI is not significant, whereas the indirect relationship (refer to Figure 3) that involves the link between SMU $\rightarrow$ IEC and IEC $\rightarrow$ GPI is significant with a coefficient value of $0.244\left(0.53^{*} 0.46\right)$. This indicates that IEC acts as a full mediator in the relationship between SMU and GP and thus hypothesis $\mathrm{H} 2$ is supported. The result is similar for the link between SMU $\rightarrow$ ECS and ECS $\rightarrow$ GPI, which is significant with a value of $0.067\left(0.28^{*} 0.24\right)$, and which implies that ECS also acts a full mediator, and thus leads to the acceptance of hypothesis $\mathrm{H} 3$. This finding clearly indicates that without strategic environmental collaboration, the use of social media alone will not help a firm to achieve GPI. 


\section{Discussion}

The finding in this study that SMU does not directly influence GPI is contrary to the findings of some previous studies. Some studies found a direct relationship between SMU and innovation performance $[17,20]$. This lack of agreement between current and previous findings may largely be due to the nature of social media itself as it can be measured in many different ways [4] depending on the interest or context of the research. For example, certain studies have measured the extent to which individuals communicate through social media and benefit from such communication specifically [80], while other studies have investigated the effects of social media users' actions more broadly [81] or have directly examined the use of social networking sites such as Facebook, LinkedIn, Twitter, etc. [82]. Furthermore, in past studies, the indicators used for innovation have represented conventional innovation in general. Therefore, the different intentions of the studies and/or the variation in the indicators used may have affected the survey responses and subsequently influenced the research findings.

However, it seems from the results that IEC acts as a bridge that connects SMU with GPI. This finding highlights the importance of exchanging information related to core work through in-house corporate communication channels $[82,83]$ and accelerating firm activities by creating more efficient cross-functional teams [3]. Basically, IEC is closely related to the concept of organizational integration which is crucial for effective environmental management [84] and this advantage encourages SMU to accelerate the sharing of new technologies and enable the effective transfer of knowledge across various departments to bring about more innovation [85,86]. In addition, firms that are implementing a dynamic environmental management strategy should always endeavour to obtain the most up-to-date information and share that information so that they can be more responsive to environmental issues [87]. However, in order to ensure that information from online sources is truly suitable for adoption, the information must first be evaluated and discussed with the firm's internal influencers before it can be exploited to achieve strategic goals [1]. Therefore, the presence of IEC is required to ensure that discussions and that decision making are optimal so as to improve GPI. Hence, the finding of this study supports the results reported by Kong et al. [25], who showed that IEC fosters green innovation.

As regards the role of ECS in connecting SMU with GPI, a previous study stated that ECS does not help in increasing the green activity of firms. However, in contrast, the finding of the current study indicates that ECS plays a critical role in connecting SMU to GPI. As stated by Benitez et al. [83] and Cheng et al. [30], leveraging SMU could improve the coordination between a firm and its supply chain, thereby further enhancing supplier involvement in the firm's product development activities. In an environmental context that is ever more challenging, it is becoming increasingly important for firms to cultivate resources and capabilities with network partners $[87,88]$. In this regard, SMU empowers employees to engage in collaborative knowledge creation [89] and, most importantly, to connect with suppliers that are well-versed in green technology. Thus, by engaging with suppliers, new environmentally friendly materials and new designs [45] could be developed at a more competitive price, and subsequently increase GPI.

Hence, overall, the findings of this study reveal that the use of social media alone does not lead to GPI. Rather, it is important to integrate environmental collaboration (IEC and ECS) into the green innovation strategies of manufacturing firms in order to meet the demands of a dynamic environment.

\section{Conclusions}

The findings of this study enrich the existing body of work on social media and its utilization and effects in the workplace from both a theoretical and practical perspective. The evolution of social media has caused it to become an important tool in managing dynamic knowledge to strengthen the GPI performance of firms. However, there is a scarcity of research on the strategies that can be employed to strengthen GPI through the use of social media. Therefore, this study sought to address this gap by investigating the extent to which the adoption and use of social media affects GPI 
performance by using some indicators for SMU that were tailored to the environmental activities and green product development of manufacturing firms. Furthermore, most of the past studies in this field have focused on general collaboration. In contrast, this study, which drew on the resource-based and relational perspectives, investigated whether two types of environmental collaboration (IEC and ECS) act as catalysts of the relationship between SMU and GPI. The resultant findings extend the existing knowledge in this field and shed further light on the important role of IEC and ECS in generating more competitive new ideas. More specifically, this study found that IEC positively influences ECS and, notably, that both IEC and ECS fully mediate the relationship between SMU and GPI.

This study also has practical implications for strategic managers as the results will help them to realign their firms' capabilities in response to environmental changes by focusing on ensuring the efficient and effective sharing of environmental knowledge within their organization. The findings show that there is a critical need to improve communication skills and enhance cross-functional collaboration among multiple divisions by sharing and endeavoring to achieve the same green mission in order to generate more creative new ideas. In addition, top management must seize the opportunity to collaborate with the right suppliers, because suppliers that are more knowledgeable and experienced in environmental management and green product development can contribute more tacit knowledge to bring about good quality innovations. Furthermore, the decision makers in firms need to provide guidance to staff on SMU by setting environmental goals and creating a favourable corporate culture so that the knowledge that is discussed and shared by employees via social media is more focused on the end goal, thus allowing for the most advantageous environmental collaborations to be established.

In closing, it should be mentioned that this study has some limitations that should be taken into account when considering the findings. Firstly, this study examined the use of social media in improving GPI in the context of environmental collaboration, which is a relatively new area of research. Hence, the indicators that were used for the constructs could be interchangeable depending on the research intent. Therefore, future studies may wish to attempt to establish a consistent set of indicators in order to achieve a more robust measurement model. They may also wish to expand the potential of SMU by examining the effects of SMU on other aspects such as corporate publicity, public relations, corporate social responsibility, and marketing communications. Secondly, this study restricted the concept of external environmental collaboration to the relationship between the firm and its suppliers, thus ignoring the interactions of the firm with its customers and other stakeholders. Therefore, future studies may wish to consider including these interactions in any further investigations.

Author Contributions: The individual contributions of the authors are as follows: Conceptualization: N.S. and M.N.A.R.; Data curation: N.S.; Formal analysis: N.S. and A.A.M.; Investigation: N.S. and M.N.A.R.; Methodology: N.S. and D.A.W.; Resources: M.N.A.R.; Software: N.S.; Supervision: M.N.A.R. and D.A.W.; Validation: N.S. and A.A.M.; Writing of original draft: N.S. and A.A.M.; Review and editing to produce final draft: M.N.A.R. and D.A.W. All authors have read and agreed to the published version of the manuscript.

Funding: This research was supported by Universiti Kebangsaan Malaysia under Grant FRGS/1/2018/TK08/UKM/02/1.

Conflicts of Interest: The authors declare no conflict of interest. The funders had no role in the design of the study; in the collection, analyses, or interpretation of data; in the writing of the manuscript, or in the decision to publish the results.

\section{References}

1. Crammond, R.; Omeihe, K.O.; Murray, A.; Ledger, K. Managing knowledge through social media modelling an entrepreneurial approach for Scottish SMEs and beyond. Balt. J. Manag. 2018, 13, 303-328. [CrossRef]

2. Kane, G.C. The evolutionary implications of social media for organizational knowledge management. Inf. Organ. 2017, 27, 37-46. [CrossRef]

3. Muninger, M.; Hammedi, W.; Mahr, D. The value of social media for innovation: A capability perspective. J. Bus. Res. 2019, 95, 116-127. [CrossRef]

4. Ahmed, Y.A.; Ahmad, M.N.; Ahmad, N.; Zakaria, N.H. Social media for knowledge-sharing: A systematic literature review. Telemat. Inf. 2019, 37, 72-112. [CrossRef] 
5. Ballew, M.T.; Omoto, A.M.; Winter, P.L. Using Web 2.0 and Social Media Technologies to Foster Proenvironmental Action. Sustainability 2015, 7, 10620-10648. [CrossRef]

6. Hynes, N.; Wilson, J. I do it, but don't tell anyone! Personal values, personal and social norms: Can social media play a role in changing pro-environmental behaviours? Technol. Forecast. Soc. Chang. 2016, 111, 349-359. [CrossRef]

7. Zhang, N.A.N.; Skoric, M.M. Media Use and Environmental Engagement: Examining Differential Gains from News Media and Social Media. Int. J. Commun. 2018, 12, 380-403.

8. Nasrollahi, M. The Impact of Firm's Social Media Applications on Green Supply Chain Management. Int. J. Supply Chain Manag. 2018, 7, 16-24.

9. Tseng, M.L.; Lim, M.K.; Wu, K.J.; Peng, W.W. Improving sustainable supply chain capabilities using social media in a decision-making model. J. Clean. Prod. 2019, 227, 700-711. [CrossRef]

10. Abbas, J.; Mahmood, S.; Ali, H.; Ali Raza, M.; Ali, G.; Aman, J.; Bano, S.; Nurunnabi, M. The Effects of Corporate Social Responsibility Practices and Environmental Factors through a Moderating Role of Social Media Marketing on Sustainable Performance of Firms' Operating in Multan, Pakistan. Sustainability 2019, 11, 3434. [CrossRef]

11. Huang, H. Media use, environmental beliefs, self-efficacy and pro-environmental behavior. J. Bus. Res. 2015, 69, 2206-2212. [CrossRef]

12. Tajudeen, F.P.; Jaafar, N.I.; Ainin, S. Information \& Management Understanding the impact of social media usage among organizations. Inf. Manag. 2017, 55, 308-321.

13. Abdullah, I.; Wan Mahmood, W.H.; Md Fauadi, H.F.; Ab Rahman, M.N.; Mohamed, S.B. Sustainable manufacturing practices in Malaysian palm oil mills: Priority and current performance. J. Manuf. Technol. Manag. 2017, 28, 278-298. [CrossRef]

14. De Medeiros, J.F.; Ribeiro, J.L.D.; Cortimiglia, M.N. Success factors for environmentally sustainable product innovation: A systematic literature review. J. Clean. Prod. 2014, 65, 76-86. [CrossRef]

15. Sujata, M.; Khor, K.S.; Ramayah, T.; Teoh, A.P. The role of social media on recycling behaviour. Sustain. Prod. Consum. 2019, 20, 365-374. [CrossRef]

16. Martín-Rojas, R.; García-Morales, V.J.; Garrido-Moreno, A.; Salmador-Sánchez, M.P. Social Media Use and the Challenge of Complexity: Evidence from the Technology Sector. J. Bus. Res. 2020, 1-19. [CrossRef]

17. Corral, G.; Zubielqui, D.; Fryges, H.; Jones, J. Social media, open innovation \& HRM: Implications for performance. Technol. Forecast. Soc. Chang. 2017, 144, 334-347.

18. Garcia-Morales, V.J.; Martín-Rojas, R.; Lardón-López, M.E. Influence of social media technologies on organizational performance through knowledge and innovation. Balt. J. Manag. 2018, 13, 345-367. [CrossRef]

19. Mention, A.; Barlatier, P.; Josserand, E. Using social media to leverage and develop dynamic capabilities for innovation. Technol. Forecast. Soc. Chang. 2019, 144, 242-250. [CrossRef]

20. Papa, A.; Santoro, G.; Tirabeni, L.; Monge, F. Social media as tool for facilitating knowledge creation and innovation in small and medium enterprises. Balt. J. Manag. 2018, 13, 329-344. [CrossRef]

21. Bhimani, H.; Mention, A.; Barlatier, P. Social media and innovation: A systematic literature review and future research directions. Technol. Forecast. Soc. Chang. 2018, 144, 251-269. [CrossRef]

22. Duan, L.; Xu, L. Da Business intelligence for enterprise systems: A survey. IEEE Trans. Ind. Inform. 2012, 8, 679-687. [CrossRef]

23. Carlson, J.; Rahman, M.; Voola, R.; Vries, N. De Customer engagement behaviours in social media: Capturing innovation opportunities. J. Serv. Mark. 2018, 32, 83-94. [CrossRef]

24. Gölgeci, I.; Gligor, D.M.; Tatoglu, E.; Ayaz, O. A relational view of environmental performance: What role do environmental collaboration and cross-functional alignment play? J. Bus. Res. 2019, 96, 35-46. [CrossRef]

25. Kong, T.; Feng, T.; Ye, C. Advanced manufacturing technologies and green innovation: The role of internal environmental collaboration. Sustainability 2016, 8, 1056. [CrossRef]

26. Solakivi, T.; Laari, S.; Töyli, J.; Ojala, L. Firm performance and environmental collaboration in manufacturing. Int. J. Bus. Syst. Res. 2017, 11, 365-392. [CrossRef]

27. Grekova, K.; Calantone, R.J.; Bremmers, H.J.; Trienekens, J.H.; Omta, S.W.F. How environmental collaboration with suppliers and customers influences firm performance: Evidence from Dutch food and beverage processors. J. Clean. Prod. 2016, 112, 1861-1871. [CrossRef]

28. Aboelmaged, M. Direct and indirect effects of eco-innovation, environmental orientation and supplier collaboration on hotel performance: An empirical study. J. Clean. Prod. 2018, 184, 537-549. [CrossRef] 
29. Segarra-Oña, M.; Peiró-Signes, Á.; Mondéjar-Jiménez, J. Twisting the twist: How manufacturing \& knowledge-intensive firms excel over manufacturing \& operational and all service sectors in their eco-innovative orientation. J. Clean. Prod. 2016, 138, 19-27.

30. Cheng, C.C.J.; Krumwiede, D.; Krumwiede, D. Enhancing the performance of supplier involvement in new product development: The enabling roles of social media and firm capabilities. Supply Chain Manag. 2018, 23, 171-187. [CrossRef]

31. Du, S.; Yalcinkaya, G.; Bstieler, L. Sustainability, Social Media Driven Open Innovation, and New Product Development Performance*. J. Prod. Innov. Manag. 2016, 33, 55-71. [CrossRef]

32. Hitchen, E.L.; Nylund, P.A.; Ferràs, X.; Mussons, S.; Hitchen, E.L.; Nylund, P.A.; Ferra, X. Social media: Open innovation in SMEs finds new support. J. Bus. Strategy 2017, 38, 21-29. [CrossRef]

33. Chen, Y.S.; Lai, S.B.; Wen, C.T. The influence of green innovation performance on corporate advantage in Taiwan. J. Bus. Ethics 2006, 67, 331-339. [CrossRef]

34. Chen, Y.S. The driver of green innovation and green image-Green core competence. J. Bus. Ethics 2008, 81, 531-543. [CrossRef]

35. Basit, A.; Hassan, Z. The Impact of Social Media Usage on Employee and Organization Performance: A Study on Social Media Tools Used by an IT Multinational in Malaysia. J. Mark. Consum. Behav. Emerg. Mark. 2018, 1, 48-65.

36. Barney, J. Firm Resources and Sustained Competitive Advantage. J. Manag. 1991, 17, 99-120. [CrossRef]

37. Mothe, C.; Nguyen-Thi, U.T. Persistent openness and environmental innovation: An empirical analysis of French manufacturing firms. J. Clean. Prod. 2017, 162, 59-69. [CrossRef]

38. Lu, Q.S.; Miller, R. How Social Media Communications Combine with Customer Loyalty Management to Boost Green Retail Sales. J. Interact. Mark. 2019, 46, 87-100. [CrossRef]

39. Hart, S.L. A Natural-Resource-Based View of the Firm. Acad. Manag. Rev. 1995, 20, 986-1014. [CrossRef]

40. Cao, X.; Yu, L. Exploring the influence of excessive social media use at work: A three-dimension usage perspective. Int. J. Inf. Manag. 2019, 46, 83-92. [CrossRef]

41. Huang, F.; Rice, J. Openness in Product and Process Innovation. Int. J. Innov. Manag. 2012, 16, 1250020. [CrossRef]

42. Rózewski, P.; Jankowski, J.; Bródka, P.; Michalski, R. Knowledge workers' collaborative learning behavior modeling in an organizational social network. Comput. Hum. Behav. 2015, 51, 1248-1260. [CrossRef]

43. Fernando, Y.; Wah, W.X. The impact of eco-innovation drivers on environmental performance: Empirical results from the green technology sector in Malaysia. Sustain. Prod. Consum. 2017, 12, 27-43. [CrossRef]

44. Stucki, T.; Woerter, M.; Arvanitis, S.; Peneder, M.; Rammer, C. How different policy instruments affect green product innovation: A differentiated perspective. Energy Policy 2018, 114, 245-261. [CrossRef]

45. Melander, L. Customer and Supplier Collaboration in Green Product Innovation: External and Internal Capabilities. Bus. Strateg. Environ. 2018, 27, 677-693. [CrossRef]

46. Taylor, B.; De Loë, R.C. Conceptualizations of local knowledge in collaborative environmental governance. Geoforum 2012, 43, 1207-1217. [CrossRef]

47. Suhariyanto, T.T.; Wahab, D.A.; Ab Rahman, M.N. Product design evaluation using life cycle assessment and design for assembly: A case study of a water leakage alarm. Sustainability 2018, 10, 2821. [CrossRef]

48. Ogbeibu, S.; Emelifeonwu, J.; Senadjki, A.; Gaskin, J.; Kaivo-oja, J. Technological turbulence and greening of team creativity, product innovation, and human resource management: Implications for sustainability. J. Clean. Prod. 2020, 244, 118703. [CrossRef]

49. Dyer, J.H.; Singh, H. Relational View. Acad. Manag. Rev. 1998, 23, 660-679. [CrossRef]

50. Sarkis, J. A boundaries and flows perspective of green supply chain management. Supply Chain Manag. 2012, 17, 202-216. [CrossRef]

51. Ageron, B.; Gunasekaran, A.; Spalanzani, A. Sustainable supply management: An empirical study. Int. J. Prod. Econ. 2012, 140, 168-182. [CrossRef]

52. Seman, N.A.A.; Govindan, K.; Mardani, A.; Zakuan, N.; Saman, M.Z.M.; Hooker, R.E.; Ozkul, S. The mediating effect of green innovation on the relationship between green supply chain management and environmental performance. J. Clean. Prod. 2019, 229, 115-127. [CrossRef]

53. Zailani, S.; Govindan, K.; Iranmanesh, M.; Shaharudin, M.R.; Sia Chong, Y. Green innovation adoption in automotive supply chain: The Malaysian case. J. Clean. Prod. 2015, 108, 1115-1122. [CrossRef]

54. Mustaffa, N.F.; Hishamuddin, H.; Mat Ropi, N.; Saibani, N.; Ab Rahman, M.N. Assessing Supply Chain Risk Management Practices in Manufacturing Industries in Malaysia. J. Kejuruter. 2018, 1, 17-22. 
55. Liao, S.H.; Hu, D.C.; Ding, L.W. Assessing the influence of supply chain collaboration value innovation, supply chain capability and competitive advantage in Taiwan's networking communication industry. Int. J. Prod. Econ. 2017, 191, 143-153. [CrossRef]

56. Ardito, L.; Messeni, A.; Dezi, L.; Castellano, S. The influence of inbound open innovation on ambidexterity performance: Does it pay to source knowledge from supply chain stakeholders? J. Bus. Res. 2018. [CrossRef]

57. Dai, J.; Cantor, D.E.; Montabon, F.L. Examining corporate environmental proactivity and operational performance: A strategy-structure-capabilities-performance perspective within a green context. Int. J. Prod. Econ. 2017, 193, 272-280. [CrossRef]

58. Mehdikhani, R.; Valmohammadi, C. Strategic collaboration and sustainable supply chain management: The mediating role of internal and external knowledge sharing. J. Enterp. Inf. Manag. 2019, 32, 778-806. [CrossRef]

59. Demeter, K.; Szász, L.; Rácz, B. The impact of subsidiaries ' internal and external integration on operational performance. Intern. J. Prod. Econ. 2016, 182, 73-85. [CrossRef]

60. Ong, T.S.; Lee, A.S.; Teh, B.H.; Magsi, H.B. Environmental Innovation, Environmental Performance and Financial Performance: Evidence from Malaysian Environmental Proactive Firms. Sustainability 2019, 11, 3494. [CrossRef]

61. Reficco, E.; Gutiérrez, R.; Jaén, M.H.; Auletta, N. Collaboration mechanisms for sustainable innovation. J. Clean. Prod. 2018, 203, 1170-1186. [CrossRef]

62. Eslami, M.H.; Lakemond, N.; Brusoni, S. The dynamics of knowledge integration in collaborative product development: Evidence from the capital goods industry. Ind. Mark. Manag. 2018, 75, 146-159. [CrossRef]

63. Hair, J.F.; Black, W.C.; Babin, B.J.; Anderson, R.E. Multivariate Data Analysis: A Global Perspective, 7th ed.; Pearson Education, Inc.: Upper Saddle River, NJ, USA, 2010.

64. Likert, R. A Technique for the Measurement of Attitudes Archives of Psychology. Arch. Psychol. 1932, 140, 1-55.

65. Yong, A.G.; Pearce, S. A Beginner's Guide to Factor Analysis: Focusing on Exploratory Factor Analysis. Tutor. Quant. Methods Psychol. 2013, 9, 79-94. [CrossRef]

66. Nunnally, J.; Bernstein, I.H. Psychometric Theory, 3rd ed.; Vaicunas, J., Belser, J.R., Eds.; McGraw-Hill, Inc.: New York, NY, USA, 1994.

67. Awang, Z. SEM Made Simple: A Guide to Learning Structural Equation Modeling; MPWS Rich Publication: Bandar Baru Bangi, Malaysia, 2015.

68. Kwahk, K.; Park, D. Computers in Human Behavior The effects of network sharing on knowledge-sharing activities and job performance in enterprise social media environments. Comput. Hum. Behav. 2016, 55, 826-839. [CrossRef]

69. Sigala, M.; Chalkiti, K. Knowledge management, social media and employee creativity. Int. J. Hosp. Manag. 2015, 45, 44-58. [CrossRef]

70. Vachon, S.; Klassen, R.D. Environmental management and manufacturing performance: The role of collaboration in the supply chain. Int. J. Prod. Econ. 2008, 111, 299-315. [CrossRef]

71. Vachon, S.; Klassen, R.D. Extending green practices across the supply chain integration. Int. J. Oper. Prod. Manag. 2006, 26, 795-821. [CrossRef]

72. Huang, Y.-C.; Yang, M.-L.; Wong, Y.-J. The effect of internal factors and family influence on firms' adoption of green product innovation. Manag. Res. Rev. 2016, 39, 1167-1198. [CrossRef]

73. Campbell, D.T. The Informant in Quantitative Research. Am. J. Sociol. 1955, 60, 339-342. [CrossRef]

74. Hooper, D.; Coughlan, J.; Mullen, M. Structural Equation Modelling: Guidelines for Determining Model Fit Structural equation modelling: Guidelines for determining model fit. J. Bus. Res. Methods 2008, 6, 53-60.

75. Hair, J.F.; Gabriel, M.; Patel, V. AMOS Covariance-Based Structural Equation Modeling (CB-SEM): Guidelines on its Application as a Marketing Research Tool. Rev. Bras. Mark. 2014, 13, 44-55.

76. Hair, J.F.; Black, W.C.; Babiin, B.J.; Anderson, R.E. Multivariate Data Analysis, 7th ed.; Prentice Hall: Upper Saddle River, NJ, USA, 2009.

77. Byrne, B.M. Structural Equation Modeling with AMOS, EQS, and LISREL: Comparative Approaches to Testing for the Factorial Validity of a Measuring Instrument. Int. J. Test. 2001, 1, 55-86. [CrossRef]

78. Henseler, J.; Ringle, C.M.; Sarstedt, M. A new criterion for assessing discriminant validity in variance-based structural equation modeling. J. Acad. Mark. Sci. 2014, 43, 115-135. [CrossRef]

79. Fornell, C.; Larcker, D.F. Evaluating Structural Equation Models with Unobservable Variables and Measurement Error. J. Mark. Res. 1981, 18, 39-50. [CrossRef] 
80. Lam, H.K.S.; Yeung, A.C.L.; Cheng, T.C.E. The impact of firms' social media initiatives on operational efficiency and innovativeness. J. Oper. Manag. 2016, 47-48, 28-43. [CrossRef]

81. Raman, R.; Menon, P. Using social media for innovation-market segmentation of family firms. Int. J. Innov. Sci. 2018. [CrossRef]

82. Braojos, J.; Benitez, J.; Llorens, J. How do social commerce-IT capabilities influence firm performance? Theory and empirical evidence. Inf. Manag. 2018, 56, 155-171. [CrossRef]

83. Benitez, J.; Castillo, A.; Llorens, J.; Braojos, J. IT-enabled knowledge ambidexterity and innovation performance in small U.S. firms: The moderator role of social media capability. Inf. Manag. 2017, 55, 131-143. [CrossRef]

84. Salim, N.; Ab Rahman, M.N.; Abd Wahab, D. A systematic literature review of internal capabilities for enhancing eco-innovation performance of manufacturing firms. J. Clean. Prod. 2019, 209, 1445-1460. [CrossRef]

85. Zhang, G.; Tang, C. How could firm's internal R\&D collaboration bring more innovation? Technol. Forecast. Soc. Chang. 2017, 125, 299-308.

86. Rahman, M.N.A.; Doroodian, M.; Kamarulzaman, Y.; Muhamad, N. Designing and validating a model for measuring sustainability of overall innovation capability of small and medium-sized enterprises. Sustainabilityy 2015, 7, 537-562. [CrossRef]

87. Martinez-Martinez, A.; Cegarra-Navarro, J.G.; Garcia-Perez, A.; Wensley, A. Knowledge agents as drivers of environmental sustainability and business performance in the hospitality sector. Tour. Manag. 2019, 70, 381-389. [CrossRef]

88. Wan Mahmood, W.H.; Ab Rahman, M.N.; Md Deros, B.; Jusoff, K.; Saptari, A.; Ebrahim, Z.; Mohamed Sultan, A.A.; Abu Bakar, M.H.; Subramonian, S.; Jano, Z. Manufacturing performance in green supply chain management. World Appl. Sci. J. 2013, 21, 76-84.

89. Mohd Suki, N. Consumer environmental concern and green product purchase in Malaysia: Structural effects of consumption values. J. Clean. Prod. 2016, 132, 204-214. [CrossRef]

Publisher's Note: MDPI stays neutral with regard to jurisdictional claims in published maps and institutional affiliations.

(C) 2020 by the authors. Licensee MDPI, Basel, Switzerland. This article is an open access article distributed under the terms and conditions of the Creative Commons Attribution (CC BY) license (http://creativecommons.org/licenses/by/4.0/). 